\title{
International Network, Social Capital and the Role of Muhammadiyah During The 2006 Yogyakarta Earthquake
}

\section{Muhammad Zahrul Anam}

Universitas Muhammadiyah Yogyakarta

Email:zahrul@umy.ac.id

\section{Sugito}

Universitas Muhammadiyah Yogyakarta

Email:Suttho77@yahoo.com

\begin{abstract}
This article aims to investigate the impact of the international network and social capital on the effectiveness of Muhammadiyah's emergency response in the 2006 Bantul earthquake. Despite paying more attention to religious and spiritual issues, Muhammadiyah, an Islamic-based social movement, plays a significant role in humanitarian issues. The 2006 earthquake in Bantul devastated public amenities, claimed thousands of people, and caused economic loss. The local government and private sectors of Bantul could not cope with the disaster. The most disaster-affected districts in Bantul Regency were Pundong, Bambanglipuro, and Jetis. Then, Muhammadiyah made an immediate emergency response to help those affected districts. In collaboration with overseas counterparts, Muhammadiyah collected humanitarian assistance. Muhammadiyah might not complete its humanitarian mission without the support of existing local Muhammadiyah in those districts. In other words, Muhammadiyah's social capital is influential for humanitarian missions. This paper utilized two concepts to elaborate on the effectiveness of Muhammadiyah's emergency response, namely transnational advocacy networks (TANs) and social capital. Then, this article argues that the higher level of TANs and social capital Muhammadiyah has, the more emergency response it can complete effectively. This paper discovered that three districts had different levels of TANs and social capital. In Pundong, the level of leverage politics (TANs) was higher than social capital. However, both Bambanglipuro and Jetis had a high level of social capital, whereas their leverage politics were low.
\end{abstract}


Keywords: Muhammadiyah, Social Capital, 2006 Earthquake, Transnational Network, Disaster

\begin{abstract}
Abstrak
Artikel ini menganalisis hubungan antara jejaring internasional dan modal sosial yang dimiliki oleh Muhammadiyah sebagai organisasi nonpemerintah berbasis agama dengan efektivitas respon kedaruratan bencana yang dilakukan oleh organisasi dimaksud. Meskipun perhatian utama organisasi keagamaan tertuju pada pengembangan aspek spritualitas, organisasi keagamaan juga mengambil peran penting dalam penyelesaian masalah-masalah kemanusiaan. Pada tahun 2006, gempa bumi yang terjadi di Yogyakarta mengakibatkan kerusakan fisik, termasuk korban jiwa dan luka-luka, yang lebih besar daripada gempa-gempa sebelumnya. Wilayah yang paling terdampak dari gempa tersebut adalah Kabupaten Bantul. Pemerintah lokal ketika itu tidak siap merespon kedaruratan gempa. Oleh karena itu, kapasitas organisasi non-pemerintah yang sanggup melakukan respon kedaruratan bencana secara efektif sangat diperlukan. Muhammadiyah segera membentuk satuan tugas khusus untuk membantu pemerintah daerah memberikan bantuan pada wilayah-wilayah terdampak di Bantul yaitu, Pundong, Bambanglipuro, dan Jetis. Selama ini, studi tentang keberhasilan dan efektifitas Muhammadiyah dalam penanggulangan bencana hanya ditinjau dari salah satu sudut pandang yaitu, modal sosial atau jejaring internasional. Namun, artikel ini melihat efektifitas tersebut dengan memadukan dua sudut pandang sekaligus baik jejaring internasional dan modal sosial. Teknik pengumpulan data dilakukan melalui wawancara pada informan dan hasilnya dianalisis dengan pendekatan tematik. Temuan artikel ini menyatakan bahwa semakin tinggi derajat modal sosial dan leverage politics (jejaring internasional), maka semakin efektif aksi tanggap darurat Muhammadiyah. Namun, semakin rendah derajat modal sosial dan semakin tinggi derajat leverage politics, maka aksi tanggap darurat Muhammadiyah hanya efektif secara sektoral, tidak masif dan divergen.
\end{abstract}

Keywords: Muhammadiyah, Modal Sosial, Gempa Yogyakarta 2006, Jejaring Internasional, Bencana. 


\section{INTRODUCTION}

On May 27, 2006, a tectonic earthquake measuring 6.2 on the Richter scale rocked Yogyakarta Special Region for approximately 57 seconds. Even though it lasted briefly, the earthquake with the epicenter in Bantul caused many casualties and considerable material damage. A tectonic earthquake of such magnitude has never happened before in Yogyakarta. Most of the earthquakes were caused by the volcanic activity of Mount Merapi. Moreover, two weeks before the earthquake, Mount Merapi's alert status was raised to four. It caused health facilities and disaster mitigation to focus on anticipating the eruption of Merapi (Purnama, 2017).

Tectonic earthquake events not previously calculated caused problems in disaster emergency response. Local government capacity was limited to respond quickly to disaster emergencies. In addition, the damage to infrastructure also prevented the government from assisting. The private sector suffered similar damage. The majority of businesspeople in Bantul were paralyzed, causing them to be unable to assist the victims. When the public and private sectors were not functioning due to capacity problems and damaged infrastructure, the role of civil society organizations in alleviating the burden on disaster victims should be considered.

In the case of the 2006 earthquake, Muhammadiyah's role started from the emergency response to the rehabilitation process. With the support of its hospitals, Muhammadiyah provided care and medical assistance to victims not accommodated in the Bantul regional hospital. Many Muhammadiyah volunteers of organizational activists and sympathizers distributed aid and carried out several post-natural disaster reconstruction activities. Muhammadiyah partnered with foreign agencies in rehabilitating disaster-affected areas in Bantul (Kedutaan Besar Australia Indonesia, 2006).

Muhammadiyah's partnership with the Australian government that provided humanitarian assistance through AusAid had succeeded in building temporary shelters that met health standards. Besides the foreign government, Muhammadiyah trusted foreign non-governmental organizations providing humanitarian aid, such as World Vision International, World Islamic Call Society, Won Buddhism, and Direct Relief International. 
Apart from partnerships, emergency response and rehabilitation activities received full support from the organizational structure at the regional, sub-regional, branch, and sub-branch levels in Bantul. Moreover, Muhammadiyah's branch organizations, such as Aisyiyah, Nasyiatul Aisyiyah, Pemuda Muhammadiyah, and its business charities, also played an active role (Barori, personal communication, December 26, 2018).

A variety of activities have proven the involvement of business charities in disaster rehabilitation activities. Muhammadiyah educational institutions mobilized students, volunteers, and consultants to carry out trauma healing. Muhammadiyah hospitals delegated medical personnel to provide health services. The Aisyiyah organization provided an economic empowerment program for mothers to help the family economy through entrepreneurship training. Then, the Angkatan Muda Muhammadiyah or Muhammadiyah Youth Force (AMM) carried out the physical reconstruction in collaboration with local sympathizers (Haikal, personal communication, January 10, 2019).

This article looks explicitly at and elaborates on the factors causing the emergency response carried out by Muhammadiyah through the concept of transnational advocacy networks (TANs) and social capital.

\section{Transnational Advocacy Networks}

Disaster emergency response carried out by community groups covers three primary stages of activity. The first stage is several disaster preparedness activities routinely performed by expert groups, including training and simulation, emergency action planning, and risk level assessment. The second stage is emergency response activities for specific disaster events, such as rescue operations and coordinating the agencies involved. The third stage deals with recovery activities conducted sometime after the disaster, such as providing temporary housing, distribution of necessities and medicines (Kasper et al., 2018).

The effectiveness of disaster emergency response can be realized in two ways: the precise distribution of responsibilities of the parties involved in assisting disaster victims and the intensity of communication and collaboration. Communication management, collaboration, and resource distribution in disaster emergency response missions are crucial issues (Krista S. Langeland, David Manheim, 2016). Initially, the humanitarian task of NGOs in the 
West, including in Australia, was to assist in situations of armed conflict. However, this humanitarian task has continued for other events outside of war that cause numerous suffering to humans (Kilby, 2015).

In Piper and Uhlin (Piper \& Uhlin, 2002), Keck and Sikkink stated that transnational advocacy networks (TANs) are networks between activists based on fundamental ideas and values. Activist actors included in TAN are highly diverse, comprising local NGOs, media, foundations, churches, trade unions, consumer organizations, academics, divisions in intergovernmental organizations, and parts of the executive or legislative bodies (Piper \& Uhlin, 2002). The strength of these networks is their ability to mobilize information strategically to create new issues and categories to gain more decisive influence from other countries or organizations. The mission of advocacy is to use information strategically to reduce relationship gaps in a global context (Piper \& Uhlin, 2002, p. 179).

1) According to Keck \& Sikkink (1999), TANs use strategies by utilizing the information to influence other large countries or organizations. These strategies include:
2) Information politics, the ability to move information quickly and credibly to the places that will be most affected

3) Symbolic politics, the ability to use symbols, actions, or stories that will make a situation make sense for the audience who are often far away

4) Leverage politics, the ability to summon strong actors to have an impact on a situation that weaker network members cannot perform

Accountability politics, an effort to give responsibility to stronger actors to act through policies or principles that these strong actors formally support (Keck \& Sikkink, 1999)

Social capital gives birth to differences in group behavior based on internal and external perspectives. Internally oriented behavior produces what Putnam called bonding (Häuberer, 2010), which focuses on strengthening the homogeneity of group bonds as seen in ethnic and religious groups. On the other hand, the perspective on external groups creates behavior that Putnam termed bridging, which mediates the relationship between group members of different social classes (Häuberer, 2010, p. 50). The Putnam concept was added 
by Pfefferbaum, who introduced the term linking social capital (Pfefferbaum et al., 2015). Social capital, referred to most recently, is the relationship between one group or network and another group or network with more power, influence, authority, and control (Pfefferbaum et al., 2015).

Regarding the disaster response by Muhammadiyah, several experts have conducted research. Al-Akbar studied the Muhammadiyah Disaster Management Center (MDMC) role in responding to the eruption of Mount Merapi in 2010. Al-Akbar concluded that a strong internal network assisted the success of MDMC. Al-Akbar also discovered that the role of disaster literacy was in line with the preaching of Muhammadiyah, which emphasizes the purification of tauhid. Society is kept away from the mythology of disasters that destroy monotheism (Akbar, 2012). Akbar's research was strengthened by Mulyasari and Shaw, who argued that Muhammadiyah's role in campaigning for disaster awareness within the organization or externally was undeniable (Mulyasari et al., 2015).

Bush explained that since 2005, the disaster response carried out by Muhammadiyah had covered three primary functions. First, Muhammadiyah's function is to rescue victims by distributing humanitarian aid and evacuating disaster victims. Second, Muhammadiyah manages international networks by selecting foreign partners who can cooperate with Muhammadiyah. Third, Muhammadiyah's function is to become a facilitator that connects aid providers from foreign agencies and recipients in disaster-affected areas (Bush, 2014a).

This article argues that the effectiveness of disaster emergency response carried out by Muhammadiyah is based on its ability to manage communication with foreign partners. In the theoretical context, this ability is termed TANs with leverage politics. Besides communicating with foreign partners, Muhammadiyah can also coordinate its internal organizational structures to support emergency response and rehabilitation programs. This capacity for internal organizational coordination became known in the concept of social capital as bonding. Previous literature discussing the effectiveness of Muhammadiyah in disaster management solely looked at the aspects of international networks or social capital. However, this study combines the two because 
international networks distributing social assistance to the affected areas cannot be carried out effectively without strong social capital.

This study employed a qualitative research method with a case study approach to the 2006 Bantul earthquake. Bantul was selected as the object of research because first: the earthquake's epicenter was in Bantul Regency, precisely in Pundong District, second: several districts in Bantul were the worst affected areas from the 2006 earthquake. This research focused on the three affected districts of Pundong, Bambanglipuro, and Jetis.

This study utilized both primary and secondary data. Primary data were collected through in-depth interviews with several informants, comprising members of the Muhammadiyah Disaster Management Center (MDMC), former organization managers, and activists at the branch level in Bambanglipuro, Pundong, and Jetis Districts, as well as representatives of the local government and activists of the Desa Tangguh Bencana or Disaster Resilient Village in Jetis and Bambanglipuro. Secondary data were gathered from written documents such as reports, scientific papers, and relevant news.
The data were then classified and analyzed using two approaches, descriptive approach and thematic analysis. A descriptive approach was used in describing Muhammadiyah's initiatives in collaborating with foreign partners. Then, thematic analysis was applied to determine humanitarian activities that worked collaboratively with foreign partners to embody leverage politics in TANs. Furthermore, the thematic analysis also looked at the social capital (bonding) of internal Muhammadiyah members through social cohesiveness in disaster emergency response and postdisaster rehabilitation. Scoring or assessing political leverage and social capital was obtained from calculating the content analysis of informants' statements.

This article looked explicitly at and elaborated on the factors causing the disaster emergency response by Muhammadiyah through the concept of TANs and social capital to determine the impact of international networks and social capital on its emergency response in the 2006 Bantul earthquake. Advocacy networks and social capital were proven through thematic analysis of primary data obtained from in-depth interviews 
and secondary data from literature studies.

Following the content analysis obtained, the authors argued that the emergency response carried out by Muhammadiyah would be widely felt if Muhammadiyah's social capital in the affected areas was strong to distribute humanitarian assistance as a result of international networks evenly. Conversely, Muhammadiyah's emergency response program would not be effective in the affected areas with weak social capital even though Muhammadiyah's international network was quite good. The effectiveness of Muhammadiyah's role in areas affected by natural disasters can be seen in the table scoring the degree of leverage politics and Muhammadiyah social capital in Pundong, Bambanglipuro, and Jetis.

\section{DISCUSSION}

Potential for Natural Disasters in the Province of Yogyakarta Special Region

The Province of Yogyakarta Special Region (DIY) has an area of 3,185.80 km (Humas DIY, 2010b). Cities in Central Java border DIY: Klaten Regency in the northeast, Wonogiri Regency in the southeast,
Purworejo Regency in the west, and Magelang Regency in the northwest (Humas DIY, 2014).

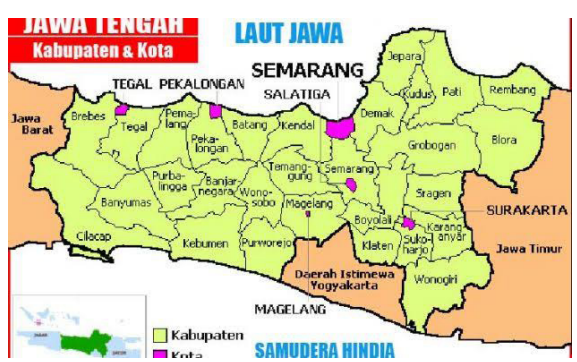

Figure 1. Map of the Special Region of Yogyakarta

Source: (SejarahNegara.com, 2020)

Yogyakarta Province consists of four regencies and one municipality: Yogyakarta City, Bantul, Kulon Progo, Sleman, and Gunung Kidul Regencies. Compared to four other regencies, Yogyakarta City has the smallest area of around $32.5 \mathrm{~km}^{2}$. Meanwhile, Gunung Kidul is the largest regency with approximately 1,485.36 km² (Badan Pusat Statistik Kabupaten Gunungkidul, 2015). Topographically, Gunungkidul and Kulon Progo Regencies are similar because they both have upland areas. Bantul and Sleman's topographical conditions are relatively flat, although they have a few hilly areas. Meanwhile, Yogyakarta City is lowland. Physiographically, the potential for natural disasters can be divided into three central potentials as follows: 
1) Natural disasters caused by volcanic activity

DIY has an active volcano called Mount Merapi. This mountain is located between Central Java and DIY. The south side of Mount Merapi is located in Sleman Regency in DIY, while the other side is in Central Java. As one of the active volcanoes in Indonesia, the activities of Mount Merapi continue to be monitored due to the large number of people living around the mountain slopes.

Active volcanoes have the potential to experience eruptions or eruptions accompanied by other natural disasters. Volcanic eruptions can cause direct and indirect natural disasters. Natural disasters that occur directly when an eruption occurs can take the form of melting lava, hot clouds, ash rain, hot lava, or the emergence of toxic volcanic gases. Meanwhile, natural disasters after the volcano erupts can form cold lava, flash floods, and volcanic avalanches (Kementerian Energi dan Sumber Daya Mineral Republik Indonesia, 2015).

In historical records, Mount Merapi has experienced dozens of eruptions that caused many losses and threatened human life around it. The worst eruption of Mount Merapi occurred in 2010 and was accompanied by hot clouds flowing from the top of the mountain toward the Gendol River. After the hot clouds, the remnants of the eruption also caused cold lava as much as 150 million $\mathrm{m}^{3}$ (Badan Geologi Kementerian Energi dan Sumber Daya Mineral, 2014).

Based on data from the National Disaster Management Agency (BNPB), the eruption of Mount Merapi in 2010 resulted in 347 fatalities, with 246 people coming from Sleman Regency. In addition, BNPB revealed data on refugees from the 2010 eruption of Mount Merapi, totaling 410,388 people (Badan Geologi Kementerian Energi dan Sumber Daya Mineral, 2014). This eruption also caused other losses in the death of livestock belonging to residents around the mountain, as many as 1,548 livestock, and damage to houses of 2,271 residents (Aco, 2020).

After the eruption in 2010, Mount Merapi has erupted several times on a small scale but did not pose a danger that threatens the safety of the surrounding population. Until now, Mount Merapi's activities are continuously monitored by the Geological Disaster Research and Technology Development Center as a form of volcano disaster mitigation. 


\section{2) Landslides and erosion}

These disasters usually threaten DIY during the rainy season. Areas that can experience landslides and erosion have sloping topologies, such as Kulonprogo and Gunungkidul Regencies. In addition, factors of high rainfall and land use can cause landslides and erosion.

Every year, the DIY Regional Disaster Management Agency (BPBD) conducts a mapping of DIY areas prone to landslides and erosion. The four regencies in DIY can experience landslides and erosion, but the highest potential occurs in Gunungkidul and Kulonprogo. Several regencies included in areas prone to landslides and erosion are Kalibawang, Girimulyo, Samigaluh, Kokap, Semin, Gedangsari, Ngawen and Patuk (Wardhani, 2020).

BPBD DIY continues to disseminate information to the public regarding landslides and erosion as part of disaster mitigation. BPBD has also installed an Early Warning System in various disaster-prone areas to determine the potential for landslides and rainfall data. Moreover, alert and observation posts were also established as preparedness to deal with landslides and erosion.

\section{3) Floods}

One of the natural disasters that often occurs in DIY is the flood. It usually occurs during the rainy season when the weather or rainfall experiences a drastic increase. It also has the greatest potential in the southern part of DIY, such as in Kulonprogo and Bantul Regencies (Humas DIY, 2010a).

The frequent floods of these two areas are not merely caused by extreme weather but also by geographical conditions, including lowland areas and large rivers. The floods that hit DIY caused property losses because residents' houses were submerged and forced to flee. In addition, floods also cause damage to public facilities and disrupt economic activities.

In addition to the three central potentials above, DIY also has the potential for natural disasters for tectonic earthquakes. Before the 2006 earthquake centered in Bantul, DIY had experienced several earthquakes. In historical records, DIY was shaken by an earthquake in 1867, resulting in many fatalities and injuries. The earthquake also caused extensive damage to infrastructure and buildings. The next earthquake occurring in DIY and its surrounding areas was in 1943. The 1943 earthquake claimed 
213 casualties, 31 of which were from DIY. An earthquake then occurred again in 1981. However, it did not cause many casualties and severe damage to buildings (Kelompok Keahlian Geodesi ITB, 2007).

Based on the recurring earthquake cycle mechanism or earthquake cycle (Kelompok Keahlian Geodesi ITB, 2007), DIY, which has experienced several earthquakes, should mitigate disasters properly as a form of preparation in minimizing losses and damage if an earthquake occurs again. Unfortunately, the number of casualties and damage to physical facilities during the 2006 earthquake indicates an unprepared emergency response.

\section{The 2006 Bantul Earthquake}

DIY Province is one of the areas prone to earthquakes. On May 27, 2006, an earthquake occurred approximately $20 \mathrm{~km}$ southeast of Yogyakarta with a shallow depth of 10 kilometers. The mainland (inland) earthquake measured 6.3 Mw. This situation resulted in severe damage to buildings and other infrastructure in several DIY areas (Kelompok Keahlian Geodesi ITB, 2007).

The 2006 earthquake caused damage to almost all DIY areas, but the most affected area was Bantul Regency. The death toll from the earthquake reached more than 4,500 people. Based on data from Yogyakarta Media Center, the majority of victims came from Bantul, approximately 4,121 people. The rest came from Sleman with 240 people, Yogyakarta City with 195 people, Gunung Kidul with 81 people, and Kulon Progo with 22 people. In addition, the number of injuries from the disaster reached 19,401 people (BAPPENAS, 2006).

Table 1. Number of Fatalities and Injuries Due to the 2006 Earthquake

\begin{tabular}{|l|l|l|}
\hline Regency/City & Fatality & Injury \\
\hline Bantul & 4,121 & 12,026 \\
\hline Sleman & 240 & 3.792 \\
\hline Kota Yogyakarta & 195 & 318 \\
\hline Gunung Kidul & 81 & 1,086 \\
\hline Kulon Progo & 22 & 2,179 \\
\hline Total & 4,659 & 19,401 \\
\hline
\end{tabular}

Source: Yogyakarta Media Center in Preliminary Damage and Loss Assessment of Natural Disasters in Yogyakarta and Central Java

(Bappenas, 2006)

Apart from fatalities and injuries, the earthquake also caused damage to buildings and infrastructure. The data revealed 
that the damage to facilities and infrastructure caused by the 2006 earthquake was much more severe than the previous earthquakes. The earthquake had caused damage to residents by destroying 88,249 house units and seriously damaged houses by 98,342 units. In addition, public facilities were also affected by the earthquake, such as the Adi Sutjipto Airport, railroad tracks, places of worship, and roads, especially in Bantul and Sleman Regencies. (BAPPENAS, 2006).

The 2006 earthquake resulted in a substantial financial loss for either DIY or Central Java. These two provinces suffered a loss of Rp. 29.1 trillion. The amount of damage reached Rp. 22.75 trillion, and the total economic loss reached Rp. 6.40 trillion. Bantul Regency had the most prominent financial loss. Compared with regional income and expenditure, the financial loss of Bantul Regency was 246\% (BAPPENAS, 2006).

The financial loss suffered by DIY, especially Bantul Regency, resulted in the local government's disaster emergency response capacity diminishing. Therefore, the local government required assistance from external parties. The central government has allocated Rp 5 trillion in funds. Apart from allocating central government funds, foreign organizations provided humanitarian assistance, such as the International Federation of Red Cross and Red Crescent Societies and agencies at the United Nations (BAPPENAS, 2006). Meanwhile, religious-based community organizations collaborated with foreign partners in carrying out disaster emergency responses in Bantul Regency.

\section{Muhammadiyah's Experience in Disaster Management}

Muhammadiyah contributed significantly to the development of Indonesian society. Its role is not only to focus on aspects of purification and renewal of Islam in Indonesia but also to improve the social conditions of the society based on the implementation of Surah Al-Ma'un. The consequence of improving community conditions has encouraged Muhammadiyah to play an active role in humanitarian activities. The institutionalization of health services and disaster management originated from the involvement of Muhammadiyah in providing humanitarian assistance to the eruption of Mount Kelud and other major disasters, such as a tsunami. 
1) History of PKU and Mount Kelud Eruption

Muhammadiyah's main foundation in humanitarian assistance refers to the Surah AlMa'un, which teaches about the urgency of helping fellow creatures of Allah SWT. Based on this foundation, Muhammadiyah has succeeded in developing diversification of social services in the community, including educational institutions and orphanages. In subsequent developments, Muhammadiyah has been involved in the health and humanitarian fields.

Muhammadiyah's movement in the health sector began with establishing the Penolong Kesengsaraan Oemoem or Oemoem Miserable Helper (PKO). The establishment of PKO was an initiative of K.H. Ahmad Dahlan's student named K.H. Sudjak. Initially, PKO was intended to provide services and social assistance to difficulties, including assisting disaster victims.

The PKO's role in the disaster emergency response movement began when Mount Kelud in East Java erupted in 1919. Mount Kelud's eruption on 19 and 20 May 1919 was accompanied by a rain of ash, rain of rocks and gravel, and hot lava. The eruption claimed 5,160 lives (BBC News, 2014). Not only causing casualties, but it also caused losses to residents. As many as 104 villages occupied by residents were severely damaged, 1,571 animals died, and several lands belonging to residents, such as rice fields and plantations, were damaged (Badan Geologi Kementerian Energi dan Sumber Daya Mineral, 2014).

The impact of the destructive eruption of Mount Kelud in 1919 led various parties to take the initiative to assist. PKO, in collaboration with the Steun Comite Keloed, conducted assistance for residents affected by the eruption. The assistance collected was in the form of funds, logistics, and health services. In the case of the Mount Kelud disaster, the assistance initiated by PKO was surplus after being distributed to victims; thus, PKO distributed a portion of the aid to help the community in DIY. PKO developed into a Pembina Kesejahteraan Umum or Public Welfare Development (PKU), which has expanded its services to empower marginalized groups, including farmers, laborers, and people with disabilities. However, PKU focuses more on the health sector, while marginalized groups are the work area of the Community Empowerment Council developed by Muhammadiyah (Syifaul, 2019). 
After health and empowerment services, Muhammadiyah saw the need to create a particular institution related to humanitarian missions, especially since Indonesia is geographically positioned in the ring of fire. In 2005, the Muhammadiyah Congress in Malang decided to establish a Lembaga Penanggulangan Bencana or Disaster Management Institute (LPB), later termed the Muhammadiyah Disaster Management Center (MDMC). The decision of the Muhammadiyah Congress to establish LPB was based on the experience of Muhammadiyah exponents in handling the 2004 Aceh Tsunami (Makhasi, 2020).

\section{2) 2004 Aceh Earthquake and Tsunami}

Before the 2006 Yogyakarta Earthquake, Aceh was hit by an earthquake measuring 9.1-9.3 on the Richter scale, accompanied by a tsunami on December 26, 2004. It was a tremendous earthquake because it was felt in Malaysia, Singapore, Thailand, Myanmar, India, and Sri Lanka. (Syamsidik et al., 2019). The height of the tsunami waves reached up to 30 meters (Yudhicara, 2014) which hit the land three times.
The death toll from the earthquake and tsunami in Aceh was 226,308 people. Of the total casualties, 173 thousand were indigenous people. Meanwhile, other casualties came from Sri Lanka with 35 thousand, India with 16 thousand, and Thailand with 8 thousand. This natural disaster displaced 1,849,827 survivors, and 394,539 refugees lived around Aceh (Syamsidik et al., 2019).

Apart from the casualties, facilities and infrastructure in Aceh were severely damaged, including government and private buildings, residential houses, and road access, which in turn crippled the economic activities of residents. Damage to public facilities has resulted in 150,000 students being unable to attend school because 1,488 school buildings were not functioning. Health services were also disrupted because approximately 26 health centers were damaged. Plantation areas of 11,000 hectares in Aceh were also damaged (Syamsidik et al., 2019).

To ease the burden on the Acehnese people, Muhammadiyah then sent humanitarian missions through the Komite Muhammadiyah Pemulihan Aceh or Aceh Recovery Muhammadiyah Committee (KMPA). Humanitarian missions 
were carried out by distributing funds, logistics, and health services. Moreover, Muhammadiyah volunteers were tasked with burying the bodies and providing health services for tsunami casualties (detikNews, 2006).

Apart from short-term disaster response programs, Muhammadiyah has also prepared five-year longterm rehabilitation programs. The rehabilitation programs initiated by Muhammadiyah are highly diverse, including the physical arrangement of the city, providing educational facilities, providing protection for children and women after the disaster, and ensuring no trafficking of children (Liputan6, 2005).

Muhammadiyah's humanitarian missions have received sympathy from various international organizations, both state and nonstate-based. Muhammadiyah's stateactor-based partners were AusAID (Australia), USAID (United States), and Saudi Arabia. Then, some international organizations working with Muhammadiyah in disaster management in Aceh were IOM, UNICEF (Bush, 2014a). Other foreign agencies based on social organizations collaborated with Muhammadiyah, such as Save the Children, Asia Foundation, and the Catholic Relief Service (Bush, 2014a).

\section{Effectiveness of Disaster Mana- gement in Bantul}

Muhammadiyah's emergency response missions in partnership with international organizations positively impacted improving people's lives after a disaster. In looking at the effectiveness of Muhammadiyah's emergency response, this section focuses on the degree of partnership associated with the concept of transnational advocacy networks (TANs) and cohesiveness associated with social capital in implementing emergency response programs in three districts in Bantul, namely, Pundong, Bambanglipuro, and Jetis.

\section{1) Pundong}

Pundong is a district in the southeastern region of Bantul Regency. One of the hamlets in Pundong, namely Potrobayan, is believed to be one of the epicenters of the 2006 Bantul earthquake (Tribunjogja.com, 2016). It was due to the Opak fault plate crossing Pundong, Imogiri, Pleret, and Piyungan Districts. The interview with Jawawi, one of the government representatives in Pundong District, revealed that the impact of the 2006 Bantul earthquake had paralyzed 
Pundong. Jawawi stated that the earthquake had a psychological impact on the Pundong community, as they were deeply traumatized.

The Pundong community received assistance from various institutions originating from within the country or abroad. The forms of assistance varied, from food to health services. However, local government services were disrupted due to the earthquake emergency, causing incomplete earthquake aid administration records. Jawawi was unable to identify with certainty the foreign aid coordinated by community organizations. Jawawi believed in the role of domestic institutions as mediators for foreign agencies performing humanitarian missions in the Pundong District.

Jawawi did not explain in more detail the names of nongovernmental organizations that acted as mediators of foreign aid, without exception Muhammadiyah. Since its inception, Muhammadiyah has allocated aid in the worst affected areas, including Pundong District. Even though Muhammadiyah had social capital in Pundong, the officials at the branch and subbranch levels and their families were primarily victims, so they were not much involved in the broader distribution of aid.

Therefore, admitted by Jawawi, victims of natural disasters in Pundong who lived far from road access had difficulty getting assistance. Jawawi emphasized that some Pundong residents, including Jawawi and his neighbors, easily accessed foreign assistance due to the position of their houses close to the road access. In Pundong District, Muhammadiyah's high political leverage was evidenced by foreign partnerships in distributing humanitarian aid. However, social capital was low because most management prioritized their families' safety and internal recovery. Therefore, the distribution of foreign aid could not be expanded and could only reach areas of which the radius was close to the aid center. The degree of leverage politics and social capital of Muhammadiyah in Pundong District can be described in the following figure. 


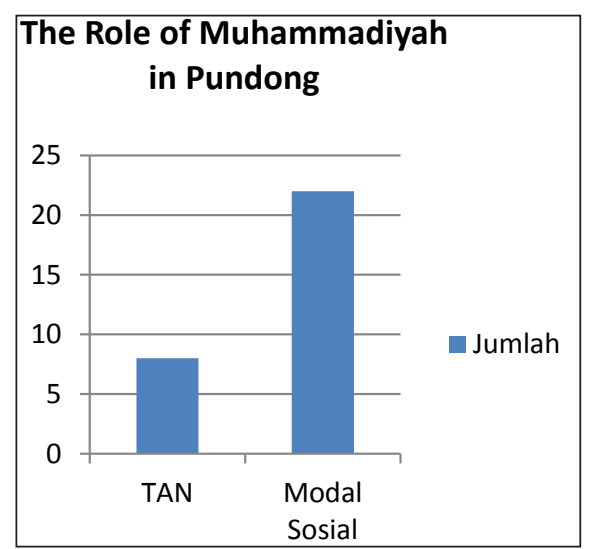

Figure 2. The Degree of Leverage Politics and Muhammadiyah Social Capital in Pundong (processed by the authors from the interview)

Figure 2 comes from a thematic analysis, illustrating that the degree of leverage of Muhammadiyah politics is very high due to partnerships with foreign institutions in collecting foreign aid in Pundong. In contrast, Muhammadiyah's social capital is low. The involvement of the Muhammadiyah structure in the Pundong District in the distribution of aid was not too high. Hence, access to assistance was felt more by residents whose radius of residence was close.

Jawawi confirmed the low social capital of Muhammadiyah during the formation of the Disaster Resilient Village (Destana). The formation of Destana was intended to make Pundong District residents better prepared for possible natural disasters. Destana is inclusive, and membership comes from representatives of villagers and community leaders. According to Jawawi, Muhammadiyah did not officially place its representatives in Destana, but rather the personal awareness of Muhammadiyah members or sympathizers to join it.

\section{2) Bambanglipuro}

Bambanglipuro is a district bordering on the east with Pundong District. Although not in the path of the Opak fault plate, the damage in Bambanglipuro due to the 2006 earthquake was exceptionally severe (Okezone, 2016). Based on interviews with Barjilan, the representative of Destana in Mulyodadi Village, Bambanglipuro, the 2006 earthquake had paralyzed the activities of the Bambanglipuro community, including those of the village administration. Moreover, the distribution of local government assistance to Mulyodadi Village in Bambanglipuro was very slow.

Initially, the local community carried out cooperation to ease the burden on other residents. Furthermore, the community received assistance from foreign agencies. Barjilan said the first aid came from Turkish NonGovernmental Organizations 
(NGOs), followed by Australia, which distributed foods.

Apart from basic foodstuffs, medical supplies and medical equipment were provided to the community from PKU Muhammadiyah in synergy with Australia. In Bambanglipuro District, Muhammadiyah established a post called People Kampong Organized (PKO). The command post coordinated the aid distributed to the community. In addition to physical needs, PKO also provided trauma healing because many survivors experienced psychological problems. Some residents lost loved family members, livelihoods, and possessions accumulated over the years. Their children faced the same problems because they lost their parents and the opportunity to go to school.

The effectiveness and success of the emergency response and Muhammadiyah rehabilitation programs are inseparable from the existence of Muhammadiyah in Bambanglipuro since 1962 . According to Sumardi, a former Pimpinan Cabang Muhammadiyah or Branch Manager of Muhammadiyah (PCM) of Bambanglipuro, most of the mosques in Bambanglipuro were founded by Muhammadiyah. The residents felt the involvement of Muhammadiyah administrators and sympathizers in the emergency response. Moreover, Din Syamsuddin, a former Chairman of the Muhammadiyah Central Executive, once visited Bambanglipuro District to ensure that humanitarian aid had been distributed to affected communities.

In Bambanglipuro District, Muhammadiyah's social capital was quite strong. This social capital was an essential element in carrying out post-disaster rehabilitation programs. Community and Muhammadiyah members in Bambanglipuro succeeded in building an emergency school with the help of an emergency tent from the Muhammadiyah Provincial Leadership of DIY. After that, the school building renovation could be conducted ideally in cooperation between Muhammadiyah and Japan, known as SD Muhammadiyah Nderman. In addition to infrastructure renovations, Muhammadiyah also held disaster preparedness training at the Komando Kesiapsiagaan Angkatan Muda Muhammadiyah or Muhammadiyah Youth Force Preparedness Command (KOKAM).

The success of Muhammadiyah's humanitarian mission in the Bambanglipuro District was 
primarily determined by the degree of cohesiveness of Muhammadiyah members rather than leverage politics (TANs). Although the number of foreign partners helping in Bambanglipuro was not as many as in other affected areas, Muhammadiyah's high degree of social capital contributed to the achievement of Muhammadiyah's humanitarian mission targets. The following is an overview of the comparison of the degree of leverage politics with social capital.

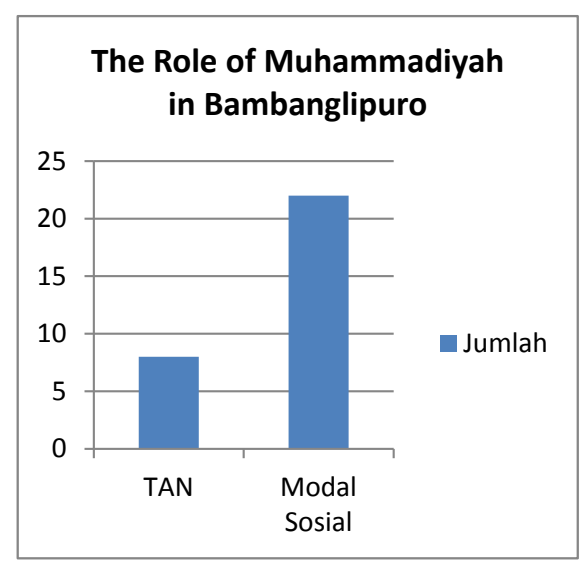

Figure 3. The Degree of Leverage Politics (TANs) and Social Capital in Bambanglipuro District (processed by the authors from the interview)

Barjilan reiterated that the contribution of residents with Muhammadiyah backgrounds in the distribution of disaster relief was enormous. Sumardi added, Muhammadiyah played a role in the socialization of Destana by inviting school heads in Bambanglipuro District, administrators of Muhammadiyah Branches (PCM) and 'Aisyiyah (PCA) Branch Managers, as well as community representatives, to support the Destana program. In this context, the local government synergized with Muhammadiyah to implement the Destana program.

\section{3) Jetis}

As in Pundong, Jetis District, located in the southeast of Bantul Regency, is included in the Opak fault plate's area (Liputan6, 2016). Therefore, the damage to physical buildings and infrastructure in Jetis was massive and severe, such as schools and residential areas. The earthquake caused tremendous anxiety among the people living in this district, especially when they encountered a tsunami.

In an uncertain psychological condition, because most communities suffered property losses and even lives, Muhammadiyah immediately took an emergency response in Jetis. Haikal, a teacher at SD Muhammadiyah Blawong and a Muhammadiyah activist, admitted that the fastest assistance to Jetis came from Muhammadiyah. The first aid was the establishment of 
refugee barracks and a command post. After the command post was established, Muhammadiyah was immediately assessed by collecting data on the number of victims. Injured victims received immediate medical attention. In addition to the evacuation barracks, Muhammadiyah also established a public kitchen assisted by the Angkatan Muda Muhammadiyah or Muhammadiyah Youth Force (AMM) in Jetis District.

The existence of Muhammadiyah and AMM administrators in Blawong Village was an advantage for Jetis District. All foreign aid collected by Muhammadiyah was first concentrated in Blawong before being distributed by the Muhammadiyah Balwong board to other villages in the vicinity. The initial assistance was logistics in the form of food. Then, Muhammadiyah, in collaboration with AusAid, established a temporary hospital to facilitate health services. Like Bambanglipuro, Muhammadiyah founded the PKO. Through PKO, Muhammadiyah built emergency schools and assistance to vulnerable groups, namely children and pregnant women. Moreover, Muhammadiyah worked on trauma healing, especially for children, through cheerful school facilities.
Haikal emphasized that the percentage of assistance attempted and distributed by Muhammadiyah exceeded the government. Muhammadiyah could bridge between foreign donor agencies and the needs of the community. Muhammadiyah's strong social capital in Blawong Village was beneficial in assisting and implementing post-disaster rehabilitation programs, resulting in more residents receiving the assistance because it was well coordinated. The effectiveness of Muhammadiyah's humanitarian mission in Blawong Village was related to the degree of social capital owned by Muhammadiyah. The degree of social capital and leverage politics (TANs) of Muhammadiyah can be illustrated in the following figure.

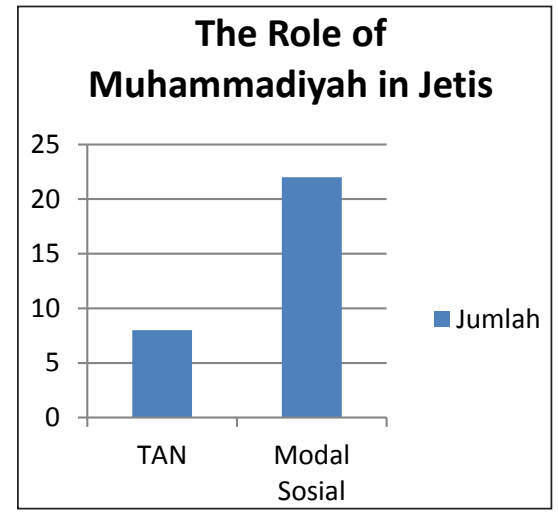

Figure 4. The Degree of Leverage Politics (TANs) and Social Capital 
in Jetis District (processed by the authors from the interview)

The experience of the 2006 Yogyakarta earthquake in Blawong Village raised the awareness of Muhammadiyah residents to increase their capacity to face the possibility of a similar disaster or other disasters. Therefore, Muhammadiyah Youth has regularly conducted disaster training to KOKAM and SAR. In addition, school children have been provided disaster simulations through the disaster-resilient school program. All disaster mitigation programs were part of the PKO program developed by Muhammadiyah administrators in Blawong Village.

\section{CONCLUSIONS}

Since its inception, Muhammadiyah has shown concern for vulnerable groups through charity movements based on Islamic teachings. Muhammadiyah's involvement in handling earthquakes and other natural disasters is understood as a manifestation of the implementation of Islamic teachings.

The 2006 Yogyakarta earthquake caused the most casualties and damage to infrastructure than other similar disasters in the previous period. The most affected area was the Bantul Regency, especially Pundong District, which was the epicenter of the tectonic earthquake, followed by Bambanglipuro and Jetis Districts.

The emergency response efforts undertaken by the local government have not been fully optimized for several reasons. First, local government infrastructure was damaged by the earthquake. Second, the local government did not prepare earthquake disaster mitigation scenarios. Due to the earthquake's impact, private groups also could not help much in the emergency response. Therefore, Muhammadiyah immediately coordinated with third parties or foreign partners to conduct emergency response and postearthquake rehabilitation in Bantul Regency.

Several foreign partners who collaborated with Muhammadiyah in responding to natural disasters included Australia, Japan, Libya, and Korea. Humanitarian aid from foreign partners distributed to the three most affected areas in Bantul-Pundong, Bambanglipuro, and Jetis Districts became the focus of Muhammadiyah's emergency response. The aid would not be distributed effectively without coordination with the 
Muhammadiyah board, members, or sympathizers in the three districts. Therefore, the effectiveness of Muhammadiyah's emergency response was primarily determined by the degree of social capital (cohesiveness) and leverage politics (transnational advocacy networks or TANs).

However, the degree of social capital and leverage politics in the three districts differed, impacting the effectiveness of aid distribution. In Pundong District, the degree of Muhammadiyah social capital was low, but its political leverage degree was high. Thus, the distribution of Muhammadiyah aid was only effective in helping residents whose homes were close to road access. Furthermore, in Bambanglipuro, the degree of social capital was high, in contrast to the degree of leverage politics, which was low. Consequently, assistance was well distributed, and the post-disaster programs were running as targeted by Muhammadiyah.

Similarly, in Jetis District, social capital was high, but the leverage politics was low. As a result, Muhammadiyah activists or sympathizers in Blawong Village in Jetis District became the vanguard for distributing humanitarian aid in other areas. Moreover, the village succeeded in forming a disaster management task force from Muhammadiyah circles, as in Bambanglipuro District.

\section{REFERENCES}

Aco, H. (2020, November 16). Inilah Kerugian Materiil Dampak Letusan Merapi-Tribunnews. com. Tribun Bisnis. https:// www.tribunnews.com / bisnis/2010/11/16/inilahkerugian-materiil-dampakletusan-merapi

Akbar, N. Al. (2012). JEJARING MUHAMMADIYAH ( Sebuah Analisis Recovery Bencana Merapi Yang Dilakukan Organisasi Muhammadiyah). 2(2).

Badan Geologi Kementerian Energi dan Sumber Daya Mineral. (2014, March 6). G. Merapi-Sejarah Letusan. Badan Geologi Kementerian Energi dan Sumber Daya Mineral. https://vsi.esdm. go.id/index.php/gunungapi/ data-dasar-gunungapi/542-gmerapi?start $=1$

Badan Pusat Statistik Kabupaten Gunungkidul. (2015). Statistik Daerah Kabupaten Gunungkidul 2015. Badan Pusat Statistik Kabupaten Gunungkidul.http:// bappeda.gunungkidulkab. 
go.id/publikasi/statistik/ STATDA\%202015.pdf

BAPPENAS. (2006). Penilaian Awal Kerusakan dan Kerugian Bencana Alam di Yogyakarta dan Jawa Tengah (No. 2). BAPPENAS.

Barori. (2018, December 26). [Personal communication].

BBC News. (2014, February 14). Sejarah letusan Gunung Kelud. BBC News Indonesia. https://www. bbc.com/indonesia/berita indonesia/2014/02/140214 sejarah_letusan_gunung_kelud

Bush, R. (2014a). Muhammadiyah and disaster response: Innovation and change in social welfare (Issue 147). Editor of the SEARCH Working Paper Series Professor Mark R Thompson Southeast Asia Research Centre.

Bush, R. (2014b). Muhammadiyah and disaster response: Innovation and change in social welfare. Southeast Asia Research Centre, 149, 1-21.

detikNews. (2006, December 28). Muhammadiyah Kirim Ribuan Relawan \& Bantuan ke Aceh. detiknews. https://news. detik.com/berita/d-263774/ muhammadiyah-kirim-ribuanrelawan--bantuan-ke-aceh
Haikal. (2019, January 10). [Personal communication].

Häuberer, J. (2010). Social Capital Theory Towards a Methodological Foundation (T. Rollnik-Manke, Ed.). VS Verlag für Sozialwissenschaften.

Humas DIY. (2010a, January 6). Potensi Bencana Alam. Pemerintah Daerah Daerah Istimewa Yogyakarta. https:// www.jogjaprov.go.id/berita/ detail/potensi-bencana-alam

Humas DIY. (2010b, June 1). Luas Wilayah. Portal Pemda DIY. https://jogjaprov.go.id/berita/ detail/luas-wilayah

Humas DIY. (2014, September 9). Batas Administrasi. Portal Pemda DIY. https://jogjaprov. go.id/berita/detail/batasadministrasi

Kasper, H., Alexander, M., Matczak, P., Pettersson, M., \& Bruzzone, S. (2018). A framework for evaluating the effectiveness of flood emergency management systems in Europe A framework for evaluating the effectiveness of flood emergency.

Keck, M. E., \& Sikkink, K. (1999). Transnational advocacy networks in international and regional politics. International Social Science Journal, 
51(159), 89-101. https://doi. org/10.1111/1468-2451.00179

Kedutaan Besar Australia Indonesia. (2006, June 16). Australia tandatangani kesepakatan Rp15 milyar lebih dengan Muhammadiyah untuk kegiatan bantuan dan kesiapan bencana Yogyakarta. Arsip Siaran Media Kedutaan Besar Australia Indonesia; corporateName $=$ Department of Foreign Affairs and Trade. https://indonesia.embassy.gov. au/jaktindonesian/SM06_21. html

Kelompok Keahlian Geodesi ITB. (2007, May 1). Studi mekanisme gempa bumi jogja 2006 menggunakan GPS Kelompok Keahlian Geodesi ITB. Kelompok Keahlian Geodesi ITB. https://geodesy. gd.itb.ac.id/2007/01/05/studigempa-jogja/

Kementerian Energi dan Sumber Daya Mineral Republik Indonesia. (2015). Booklet Gunung Api. Kementerian Energi dan Sumber Daya Mineral Republik Indonesia. https://www.esdm.go.id/assets/ media/content/Pengenalan Gunung_Api.pdf

KILBY, P. (2015). Emergency Responses and Humani- tarianism Book. In NGOs and Political Change. ANU Press.

Krista S. Langeland, David Manheim, G. M. and G. N. (2016). Disaster Response and Recovery-Oriented Resilience.

Liputan6. (2005, February 1). Muhammadiyah Mempersiapkan Program Bantuan Jangka Panjang Aceh. Liputan6.Com. https:// www.liputan6.com/news/ read/92991/muhammadiyahmempersiapkan-programbantuan-jangka-panjang-aceh Liputan6. (2016, May 29). Secar Opak dan Gempa Yogya 2006News Liputan6.com. Liputan6. Com. https://www.liputan6. com/news/read/2518566/secaropak-dan-gempa-yogya-2006

Makhasi, G. Y. M. (2020, June 10). Mengenal MDMC (Muhammadiyah Disaster Management Center. Forum Perpustakaan Perguruan Tinggi Muhammadiyah / Aisyiyah. http://www.fpptma. or.id/2020/06/mengenalmd mc-muham madiyah disaster.html

Mulyasari, F., Shaw, R., \& Civil, C. (2015). Community-Based Disaster Risk Reduction Article information: In Community, 
Environment and Disaster Risk Management (Vol. 10). Emerald Group Publishing Ltd. https://doi.org/10.1108/S20407262(2012)0000010014

Okezone. (2016, May 27). Ini Jalur Gempa Yogyakarta pada 2006: Okezone News. https://news.okezone.com/. https://news.okezone.com/ $\mathrm{read} / 2016 / 05 / 27 / 510 / 1399150 /$ ini-jalur-gempa-yogyakartapada-2006

Pfefferbaum, B., Horn, R. L. Van, \& Pfefferbaum, R. L. (2015).

A Conceptual Framework to Enhance Community Resilience Using Social Capital. Clinical Social Work Journal. https:// doi.org/10.1007/s10615-0150556-Z

Piper, N., \& Uhlin, A. (2002). Transnational Advocacy Networks, Female Labor Migration and Trafficking in East and Southeast Asia:

A Gendered Analysis of Opportunities and Obstacles *. Asian and Pacific Migration Journal, 171-195.

Purnama, S. G. (2017). Modul manajemen Universitas bencana. Udayana. https://simdos.unud.ac.id/ uploads/file_pendidikan_ dir / a b bf 7 e 649748 d 49 cbf426b1db1b8bc01.pdf

SejarahNegara.com. (2020, March 7). Indonesia negara terbesar di Asia Tenggara. Sejarah Negara Com. https://www.sejarah-negara. com/72991/indonesia/

Syamsidik, Nugroho, A., Oktari, R. S., \& Fahmi, M. (2019). ACEH PASCA 15 TAHUN TSUNAMI: Kilas Balik dan Proses Pemulihan. Tsunami and Disaster Mitigation Research Center. https://bpba. acehprov.go.id/uploads/ACEH_ PASCA_15_TAHUN_TSUNAMI. pdf

Syifaul. (2019, May 20). 100 Tahun Letusan Kelud dan Pendirian Penolong Kesengsaraan Oemoem (PKO). Solo Pos. https://www. solopos.com/100-tahun-letusankelud-dan-pendirian-penolongkesengsaraan-oemoem-pko-993480

Tribunjogja.com. (2016, May 24). Peringati 10 Tahun Gempa, Warga Bantul Bangun Monumen di Dekat Pusat Gempa. Tribun Jogja. https://jogja.tribunnews. com/2016/05/24/peringati-10tahun-gempa-warga-bantulbangun-monumen-di-dekat-pusatgempa

Wardhani, C. M. (2020, August 1). BPBD DIY Petakan Daerah Rawan Longsor dan Siapkan Posko- 


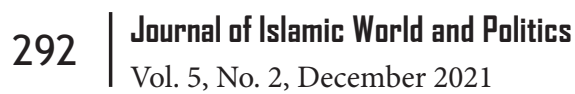

Tribun Jogja. Tribun Jogja. https:// jogja.tribunnews.com/2020/01/08/ bpbd-diy-petakan-daerah-rawanlongsor-dan-siapkan-posko

Yudhicara. (2014, December 31). Mengukur Dampak Tsunami Aceh 2004. Geomagz. http:// geomagz.geologi.esdm.go.id/ mengukur-dampak-tsunamiaceh-2004/ 